\title{
STUDI IDENTIFIKASI KERUSAKAN WILAYAH PESISIR DI KABUPATEN MUKOMUKO PROVINSI BENGKULU
}

\author{
Zamdial, Dede Hartono, Deddy Bakhtiar, Eko Nofridiansyah \\ Program Studi IImu Kelautan Universitas Bengkulu \\ email : zamdial_et@yahoo.co.id
}

Received August 2017, Accepted September 2017

\begin{abstract}
ABSTRAK
Kabupaten Mukomuko berada di Provinsi Bengkulu yang mempunyai wilayah pesisir dengan panjang garis pantai $\pm 98,218 \mathrm{~km}$. Dinamika alam yang terjadi pada beberapa tahun terakhir, seperti halnya perubahan iklim dan tekanan dari manusia yang makin parah memberi dampak yang nyata terhadap kondisi wilayah pesisir. Fenomena yang dijumpai adalah terjadinya kerusakan diwilayah pesisir yang semakin cepat. Penelitian ini bertujuan untuk mengindentifikasi kerusakan yang terjadi disepanjang wilayah pesisir Kabupaten Mukomuko, Provinsi Bengkulu dan memetakan lokasi wialayah pesisir yang sudah rusak. Penelitian ini dilakukan selama 15 hari pada bulan Oktober 2014. Penelitian dilakukan dengan metode survei yang meliputi kegiatan observasi lapangan, wawancara dan dokumentasi kondisi kerusakan wilayah pesisir. Data hasil penelitian dianalisis secara deskriptif. Untuk mengindentifikasi kerusakan wilayah pesisir digunakan analisis Indeks Kerentanan Pantai (IKP). Hasil penelitian menunjukkan bahwa terdapat 9 lokasi kerusakan wilayah pesisir di Kabupaten Mukomuko dengan IKP secara berturut-turut yaitu Pantai Air Hitam-TWA (IKP=12), Pantai Air Rami (IKP=13,9), Rawa Bangun $(\mathrm{IKP}=14,7)$, Pantai Retak Ilir $(\mathrm{IKP}=17)$, Hutan Suaka Alam Mukomuko $(\mathrm{IKP}=19,6)$, Pantai Desa Air Dikit (IKP=19,6), Desa Pasar Bantal (IKP=24), Pantai Desa Air Buluh (IKP=22,6), dan Pantai Pasar Ipuh (IKP=55,1). Nilai IKP yang tertinggi adalah 55,1 dan yang terendah adalah 12 . Wilayah pesisir Kabupaten Mukomuko secara umum sudah mengalami degradasi. Penyebab degradasi antara lain adalah rusaknya hutan pantai, alih fungsi lahan, abrasi, perubahan morfologi pantai dan pembangunan fisik.
\end{abstract}

Kata Kunci : IKP, Kerusakan, Wilayah Pesisir, Mukomuko

\section{ABSTRACT}

Mukomuko Regency is located in Bengkulu Province which has coastal area with long coastline $\pm 98,218 \mathrm{~km}$. The natural dynamics that have occurred in recent years, as well as climate change and pressure from human activities that is getting worse, have had a significant impact on conditions of coastal regions. The phenomenon encountered is the 
occurrence of damage in the coastal region is getting faster. This study aims to identify the damage that occurred along the coastal regions of Mukomuko Regency, Bengkulu Province and mapped the location of coastal regions that is damaged. This research was conducted for 15 days in October 2014. The research was conducted by survey method which includes field observation, interview and documentation of coastal damage condition. The data of the research were analyzed descriptively. To identify the damage of coastal regions was used the Coastal Vulnerability Index (CVI). The results showed that there were 9 locations of coastal damage in Mukomuko Regency with IKP respectively, namely Air Hitam Coast-TWA (IKP = 12), Air Rami Coast (IKP = 13.9), Rawa Bangun (IKP = 14,7) ), Retak Ilir Coast (IKP = 17), Mukomuko Nature Forest Conservation (IKP = 19.6), Air Dikit Village Coast (IKP = 19.6), Pasar Bantal Village (IKP =24), Air Buluh Village (IKP =22.6), and Pasar Ipuh Coast $(I K P=55.1)$. The highest value of IKP is 55.1 and the lowest is 12 . The coastal regions of Mukomuko Regency generally has been degraded. The causes of degradation include coastal forest destruction, land conversion, abrasion, coastal morphological changes and physical development.

Keywords: CVI, Damage, Coastal Regions, Mukomuko

\section{PENDAHULUAN}

Secara geografis wilayah Kabupaten Mukomuko terletak pada 101001'15,1" -101051'29,6" BT dan pada 02016'32,0"- 03007'46,0"LS, dengan panjang garis pantai $\pm 98,218 \mathrm{~km}$ dan luas perairan laut $\pm 727,60$ $\mathrm{km}^{2}$ jika dihitung sejauh 4 mil dari garis pantai (Bappeda Kabupaten Mukomuko, 2011). Kabupaten Mukomuko termasuk satu dari tujuh wilayah kabupaten/kota di Propinsi Bengkulu yang memiliki wilayah pesisir, karena terletak di Pantai Barat Pulau Sumatera dan berbatasan langsung dengan Samudera Hindia.

Wilayah pesisir secara sederhana dapat dipandang sebagai wilayah yang berbatasan dengan laut dan daratan. Menurut Setyawan et al (2015), kawasan pesisir adalah daerah peralihan atau tempat pertemuan antara daratan dan laut, yang mencakup lingkungan tepi pantai dan perairan pantai. La Sara (2014) menjelaskan, bahwa secara ekologi wilayah pesisir merupakan ecotone mewakili transisi dari daratan ke pengaruh-pengaruh dari laut. Wibisono (2011), secara rinci menjelaskan, pengertian pesisir bisa dijabarkan dari dua segi yang berlawanan, yakni dari segi daratan; wilayah pesisir adalah wilayah daratan sampai wilayah laut yang masih dipengaruhui sifat-sifat darat (seperti angin darat, drainase air tawar dari sungai, sedimentasi), dan dari segi laut; wilayah pesisir adalah wilayah laut sampai wilayah darat yang masih dipengaruhi sifat-sifat laut (seperti pasang surut, salinitas, intrusi air laut ke wilayah daratan, angin laut dan lain-lain).

Sebagai kawasan yang strategis dan memiliki potensi yang sangat besar, daerah pesisir di Kabupaten Mukomuko merupakan sudah sejak 
lama memberikan manfaat yang besar kepada masyarakat, terutama masyarakat yang bermukim di sepanjang wilayah pesisir tersebut. Pemanfaatan potensi wilayah pesisir oleh menunjukkan peningkatan yang sangat tajam dari waktu ke waktu, baik oleh masyarakat maupun pemanfaatan untuk kepentingan pembangunan. Adakalanya pemanfaatan potensi wilayah pesisir tidak lagi sesuai dengan daya dukung dan azas pemanfaatan secara optimal dan berkelanjutan. Pengelolaan daerah pesisir pada prinsipnya berkaitan erat dengan faktor ekologis, ekonomi dan sosial yang saling berhubungan satu sama lain. Timbulnya masalah dalam pengelolaan dan pemanfaatan daerah pesisir antara lain karena ketiga faktor tersebut tidak berjalan secara serasi dan seimbang.

Aktivitas ekonomi dan non-ekonomi masyarakat pesisir di kawasan pesisir Kabupaten Mukomuko, Provinsi Bengkulu memberikan dampak terhadap ekosistem masyarakat pesisir. Dampak yang paling nyata di kawasan pesisir dengan eksploitasi sumberdaya adalah degradasi kondisi bio-fisik sumberdaya pesisir. Sepanjang daerah di kawasan pesisir Kabupaten Mukomuko, Provinsi Bengkulu terjadi abrasi air laut, yang berarti pula terjadi sedimentasi dan penurunan luasan vegetasi pantai.

Meskipun sebagian data tentang ekosistem dan masyarakat pesisir Provinsi Bengkulu telah tersedia, namun data tersebut tidak mampu lagi mempresentasikan kondisi yang terjadi saat ini. Hal ini karena aktivitas yang terjadi di kawasan pesisir merupakan aktivitas yang sangat dinamis, selalu terjadi perubahan pada setiap waktunya. Apa lagi dengan adanya fenomena naiknya level muka air laut sebagai dampak dari pemanasan global yang menyebabkan intensitas kerusakan wilayah pesisir akibat abrasi, pasang tinggi, dan sedimentasi juga terus meningkat. Untuk itu, kegiatan identifikasi kerusakan daerah pesisir Kabupaten Mukomuko, Provinsi Bengkulu menjadi penting untuk dilakukan sebagai langkah antisipasi dan aksi untuk menghadapi kerusakan wilayah pesisir tersebut.

Maksud pelaksanaan kegiatan ini adalah untuk mendapatkan informasi dan data yang mampu menggambarkan kondisi aktual tentang kerusakan yang terjadi di daerah pesisir Provinsi Bengkulu. Data dan informasi yang tersusun diharapkan dapat menjadi salah satu landasan pengambilan kebijakan dan penyusunan program bagi pemerintah daerah serta menjadi informasi yang berguna bagi masyarakat dalam upaya mengurangi resiko bencana di kawasan pesisir.

Kegiatan penelitian ini bertujuan untuk untuk mengindentifikasi kerusakan yang terjadi disepanjang wilayah pesisir Kabupaten Mukomuko, Provinsi Bengkulu dan memetakan lokasi wialayah pesisir yang mengalami kerusakan.

\section{MATERI DAN METODE}

Kegiatan studi identifikasi kerusakan wilayah pesisir di Kabupaten Mukomuko, Provinsi Bengkulu ini dilaksanakan selama 15 hari yaitu pada bulan Oktober 2014. Kegiatan ini dilaksanakan di sepanjang wilayah pesisir Kabupaten Mukomuko Provinsi Bengkulu yang meliputi wilayah pesisir di Kecamatan XIV Koto, Kecamatan Kota Mukomuko, Kecamatan 
Air Dikit, Kecamatan Teramang Jaya, Kecamatan Pondok Suguh, Kecamatan Sungai Rumbai, Kecamatan Ipuh dan Kecamatan Air Rami.

Data yang dikumpulkan terdiri dari data primer dan data sekunder. Data primer diperoleh menggunakan metode survei melalui observasi lapangan, wawancara mendalam (deep interview) dengan beberapa responden yang dipilih secara purposive dan incidental di lokasi kerusakan daerah pantai dan dokumentasi kerusakan sepanjang wilayah pesisir. Instrumen pengumpulan data yang digunakan dalam penelitian ini yaitu kuisioner, pedoman wawancara dan kamera. Data skunder diperoleh menggunakan metode studi pustaka/literatur.

Ruang lingkup kerusakan yang disurvei yaitu seluruh kerusakan di wilayah pesisir Kabupaten Mukomuko, yang berada di atas permukaan air yang dapat diamati dan diidentifikasi secara langsung tanpa memerlukan analisis lanjutan/analisis laboratorium (dalam hal ini survei yang dilakukan tidak termasuk ekosistem bawah air seperti terumbu karang dan lamun). Survei lapang yang dilakukan bertujuan untuk mengamati kerusakan di wilayah pesisir, kemudian dilanjutkan dengan mengidentifikasi kerusakan tersebut. Hasil akhir dari identifikasi ini yaitu dapat mendeskripsikan: (a) Jenis kerusakan yang terjadi disuatu daerah atau lokasi pesisir; (b) Penyebab terjadinya kerusakan disuatu daerah atau lokasi pesisir; (c) Dampak atau akibat dari kerusakan yang terjadi disuatu daerah atau lokasi pesisir; (d) Alternatif penanggulangan/rehabilitasi daerah pesisir yang mengalami kerusakan; dan (e) Lokasi detail (koordinat lokasi) daerah pesisir yang mengalami kerusakan.

Untuk menganalisis data yang sudah diperoleh digunakan metode analisis deskriptif. Metode ini digunakan untuk menggambarkan data dalam bentuk bahasa secara runtut atau dalam bentuk naratif, yang mana data-data yang digunakan disajikan dalam bentuk matriks, tabel, chart ataupun peta sehingga lebih mudah untuk dipahami dan dimengerti.

Selanjutnya data tentang kerusakan daerah pesisir Kabupaten Mukomuko, Provinsi Bengkulu di analisis lebih lanjut menggunakan analisis Indeks Kerentanan Pantai (IKP). Analisis Indeks Kerentanan Pantai ini digunakan untuk menentukan lokasi/daerah mana yang mengalami kerusakan cukup tinggi dan memiliki resiko kerugian/keruskan yang besar apabila tidak segera ditangani. Rumus Indeks Kerentanan Pantai (IKP) yang digunakan yaitu rumus dari Boruf et al (2005) :

$$
\mathrm{IKP}=\sqrt{\frac{\text { Perkalian Bobot Semua Variabel }}{\text { Jumlah Variabel }}}
$$

Dari perhitungan menggunakan rumus tersebut ditentukan tingkat kerentanan pantai daerah pesisir Kabupaten Mukomuko, Provinsi Bengkulu dengan ketentuan sebagai berikut :
IKP 0-25 : Kerentanan rendah
IKP 25-50 : Kerentanan sedang
IKP 50-75 : Kerentanan tinggi
IKP 75-100 : Kerentanan sangat tinggi 
Variabel yang digunakan dalam analisis IKP ada 8 variabel yaitu : Perubahan Garis Pantai (PP) berdasakran hasil wawancara, Pengamatan Visual Kerusakan (K), Panjang Kerusakan (PK), Lebar Kerusakan(LK), Lebar Sabuk Hijau (SH), Litologi Pantai (L), Penggunaan Lahan (PL), dan Kemiringan Pantai $(\beta)$. Menurut Jensent et al (1993) dan NoRONHA et al, (2003) dalam Boruf et al (2005).

Selanjutnya untuk menentukan nilai bobot untuk masing-masing variabel di masing-masing lokasi kerusakan digunakan ketentuan pembobotan seperti pada Tabel 1 berikut ini. Pembobotan variable fisik dilakukan dengan membagi nilai variable menjadi 5 (lima) tingkatan, dari yang paling ringan sampai yang paling berat kerusakannya (Gornitz et al. ,1997; Boruff et al., 2005 dan DKP, 2004 dalam Wahyudi et al. (2009).

Tabel. 1. Ketentuan Pembobotan masing-masing variabel IKP

\begin{tabular}{|c|c|c|c|c|c|c|}
\hline \multirow[t]{2}{*}{ No } & \multirow[t]{2}{*}{ Variabel } & \multicolumn{5}{|c|}{ Bobot } \\
\hline & & 1 & 2 & 3 & 4 & 5 \\
\hline 1 & $\begin{array}{l}\text { Perubaha } \\
\text { n Garis } \\
\text { pantai } \\
\text { (PP) } \\
\text { (Dari } \\
\text { hasil } \\
\text { Wawanca } \\
\text { ra) }\end{array}$ & $0 \mathrm{~m} / \mathrm{th}$ & $\begin{array}{c}(0-1) \\
/ \text { th }\end{array}$ & $\begin{array}{l}(1-5) \\
\mathrm{m} / \mathrm{th}\end{array}$ & $(5-10) \mathrm{m} / \mathrm{th}$ & $>10 \mathrm{~m} / \mathrm{th}$ \\
\hline 2 & $\begin{array}{l}\text { Pengama } \\
\text { tan Visual } \\
\text { Keruskan } \\
\text { (K) }\end{array}$ & $\begin{array}{l}\text { Terlihat } \\
\text { Gejala } \\
\text { gerusan }\end{array}$ & $\begin{array}{l}\text { Terlihat } \\
\text { gerusan } \\
\text { tapi } \\
\text { masih } \\
\text { stabil }\end{array}$ & $\begin{array}{l}\text { Terjadi } \\
\text { gerusan } \\
\text { dan } \\
\text { akan } \\
\text { terjadi } \\
\text { runtuha } \\
\text { n }\end{array}$ & $\begin{array}{l}\text { Terjadi } \\
\text { gerusan } \\
\text { dan } \\
\text { runtuhan } \\
\text { tetapi } \\
\text { belum } \\
\text { membahay } \\
\text { akan } \\
\text { sarana/pra } \\
\text { sarana }\end{array}$ & $\begin{array}{l}\text { Terjadi } \\
\text { gerusan } \\
\text { dan } \\
\text { runtuhan } \\
\text { dan } \\
\text { membaha } \\
\text { yakan } \\
\text { sarana } \\
\text { dan } \\
\text { prasarana }\end{array}$ \\
\hline 3 & $\begin{array}{l}\text { Panjang } \\
\text { keruskan } \\
\text { (PK) }\end{array}$ & $<0,5 \mathrm{~m}$ & $\begin{array}{l}0,5-2 \\
\mathrm{~km}\end{array}$ & $2-5 \mathrm{~km}$ & $5-10 \mathrm{~km}$ & $>10 \mathrm{~km}$ \\
\hline 4 & $\begin{array}{l}\text { Lebar } \\
\text { Kerusaka } \\
\text { n (LK) }\end{array}$ & $0 \mathrm{~m}$ & $1-10 \mathrm{~m}$ & $\begin{array}{l}10-50 \\
m\end{array}$ & $50-100 \mathrm{~m}$ & $>100 \mathrm{~m}$ \\
\hline 5 & $\begin{array}{l}\text { Lebar } \\
\text { sabuk } \\
\text { Hijau }\end{array}$ & $\begin{array}{l}> \\
\mathrm{km}\end{array}$ & $\begin{array}{l}(1000- \\
1500) \\
\mathrm{km}\end{array}$ & $\begin{array}{l}(500- \\
1000) \\
\mathrm{km}\end{array}$ & $\left.\begin{array}{ll}(50 & -500\end{array}\right)$ & $<50 \mathrm{~m}$ \\
\hline
\end{tabular}


$(\mathrm{LH})$

$6 \quad$ Litologi

(L)

\begin{tabular}{|c|c|c|c|c|}
\hline \multicolumn{2}{|c|}{ Batuan } & \multicolumn{3}{|c|}{ Sedimen } \\
\hline $\begin{array}{l}\text { Batuan } \\
\text { beku, } \\
\text { sedimen } \\
\text { 'metamo } \\
\text { rf, } \\
\text { kompak } \\
\text { dan } \\
\text { keras }\end{array}$ & $\begin{array}{l}\text { Batuan } \\
\text { beku, } \\
\text { sedimen } \\
\text { berbutir } \\
\text { halus, } \\
\text { kompak } \\
\text { dan } \\
\text { lunak }\end{array}$ & $\begin{array}{l}\text { Gravel } \\
\text { dan } \\
\text { Pasir } \\
\text { Kasar } \\
\text { agak } \\
\text { Kompak }\end{array}$ & $\begin{array}{l}\text { Pasir, } \\
\text { Lanau, } \\
\text { lempung } \\
\text { agak } \\
\text { Kompak }\end{array}$ & $\begin{array}{l}\text { Pasir, } \\
\text { lanau, } \\
\text { Lempung } \\
\text {, Lumpur, } \\
\text { Lepas }\end{array}$ \\
\hline $\begin{array}{l}\text { Tegalan } \\
\text {, Hutan } \\
\text { Bakau, } \\
\text { tanah } \\
\text { Kosong } \\
\text { dan } \\
\text { Rawa }\end{array}$ & $\begin{array}{l}\text { Daerah } \\
\text { Wisata } \\
\text { Domesti } \\
\text { k, } \\
\text { Tambak } \\
\text { tradision } \\
\text { al, } \\
\text { Perkebu } \\
\text { nan }\end{array}$ & $\begin{array}{l}\text { Persaw } \\
\text { ahan } \\
\text { dan } \\
\text { tambak } \\
\text { Intensif }\end{array}$ & $\begin{array}{l}\text { Pemukima } \\
\text { n, } \\
\text { Pelabuhan } \\
\text { Perkantora } \\
\text { n, Sekolah, } \\
\text { dan Jalan } \\
\text { Propinsi }\end{array}$ & $\begin{array}{l}\text { Cagar } \\
\text { Budaya, } \\
\text { Daerah } \\
\text { Wisata } \\
\text { Berdevis } \\
\text { a, } \\
\text { Industri, } \\
\text { Jalan } \\
\text { Negara } \\
\text { dan } \\
\text { Fasiltas } \\
\text { Pertahan } \\
\text { an } \\
\text { Negara }\end{array}$ \\
\hline 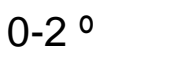 & 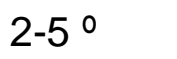 & $5-10^{\circ}$ & $10-15$ 인 & $>15^{\circ}$ \\
\hline
\end{tabular}

\section{HASIL DAN PEMBAHASAN}

Wilayah pesisir Kabupaten Mukomuko memanjang dari arah Barat Laut (di perbatasan dengan Propinsi Sumatera Barat) sampai arah Tenggara (sebelah Selatan Air Rami), membentuk garis pantai yang relatif lurus. Wilayah pesisir dikenal sebagai wilayah yang kaya dengan berbagai sumberdaya alam yang dapat dimanfaatkan oleh manusia untuk kepentingan hidupnya. La Sara (2014) mengemukakan, bahwa banyak negara yang menjadi sumberdaya pesisir tersebut sebagai modal dasar pelaksanaan pembangunan. Selanjutnya dijelaskan, bahwa di wilayah pesisir terdapat sumberdaya alam yang sangat produktif seperti coral reef , padang lamun (seagrass), hutan mangrove, sumberdaya perikanan (berbagai jenis ikan, crustacea dan mollusca) dan daerah perlindungan laut atau wilayah konservasi. 
Sebagaimana wilayah pesisir umumnya, sumberdaya alam yang dapat dijumpai di wilayah pesisir Kabupaten Mukomuko terdiri berbagai ekosistem hayati dan sumberdaya non-hayati. Ekosistem hayati antara lain adalah ekosistem mangrove, ekosistem hutan pantai, dan ekosistem perairan, sedangkan sumberdaya non-hayati yang dominan adalah batu koral dan pasir laut. Ekosistem mangrove di Kabupaten Mukomuko tidak begitu banyak, dan terpencar-pencar. Sepanjang pesisir Kabupaten Mukomuko, ekosistem mangrove dapat dijumpai di Desa Pasar Sebelah, Desa Bandar Ratu, Pasar Mukomuko dan di Desa Air Hitam.

Hutan pantai di kawasan pesisir Kabupaten Mukomuko, saat ini sebagian besar sudah banyak berubah fungsinya dari ekosistem penyangga (buffer region) atau sebagai jalur hijau, menjadi lahan pertanian, perkebunan dan pemukiman. Pada beberapa lokasi, hutan pantai juga berstatus sebagai Hutan Cagar Alam dan Taman Wisata Alam (TWA). Hutan Cagar Alam ada antara Kota Mukomuko sampai Desa Air Dikit dan Desa Air Rami, sedangkan TWA adalah di Desa Air Hitam. Perambahan dan pembukaan hutan pantai menjadi lahan pertanian dan perkebunan semakin tinggi, walaupun sudah dilakukan pelarangan. Kondisi ini jika dibiarkan terus menerus dapat mendorong kerusakan wilayah pesisir yang lebih parah.

Secara umum kondisi wilayah pesisir Kabupaten Mukomuko sudah mengalami degradasi. Hasil identifikasi kerusakan wilayah pesisir Kabupaten Mukomuko disajikan pada Tabel 3 berikut ini.

Tablel 2. Lokasi, jenis, penyebab, dampak kerusakan IKP dan Alternatif Penanggulangan kerusakan daerah pesisir Kabupaten Mukomuko, Provinsi Bengkulu

\begin{tabular}{|c|c|c|c|c|c|}
\hline No & Lokasi & $\begin{array}{l}\text { Kerusakan/Penye } \\
\text { bab Kerusakan }\end{array}$ & Dampak & $\mathrm{IKP}$ & $\begin{array}{l}\text { Alternatif } \\
\text { Penanggulang } \\
\text { an }\end{array}$ \\
\hline 1 & $\begin{array}{l}\text { Rawa } \\
\text { Bangun } \\
\text { (SP 10), } \\
\text { Pasar } \\
\text { Sebelah } \\
\text { dan } \\
\text { Pantai } \\
\text { Indah } \\
\text { Mukomu } \\
\text { ko }\end{array}$ & $\begin{array}{ll}\text { Rusaknya } & \text { hutan } \\
\text { pantai, Alih fungsi } \\
\text { hutan pantai, } \\
\text { Abrasi }\end{array}$ & $\begin{array}{l}\text { Hilangnya } \\
\text { hutan } \\
\text { pantai, } \\
\text { berkurangn } \\
\text { ya lebar } \\
\text { pantai }\end{array}$ & $\begin{array}{l}14, \\
7\end{array}$ & $\begin{array}{l}\text { Penanaman } \\
\text { kembali hutan } \\
\text { pantai, } \\
\text { pelarangan } \\
\text { alih fungsi } \\
\text { lahan pantai } \\
\text { (Perda dan } \\
\text { Perdes), } \\
\text { bangunan } \\
\text { pengaman } \\
\text { pantai } \\
\text { (revetment/groi } \\
\text { n) }\end{array}$ \\
\hline
\end{tabular}




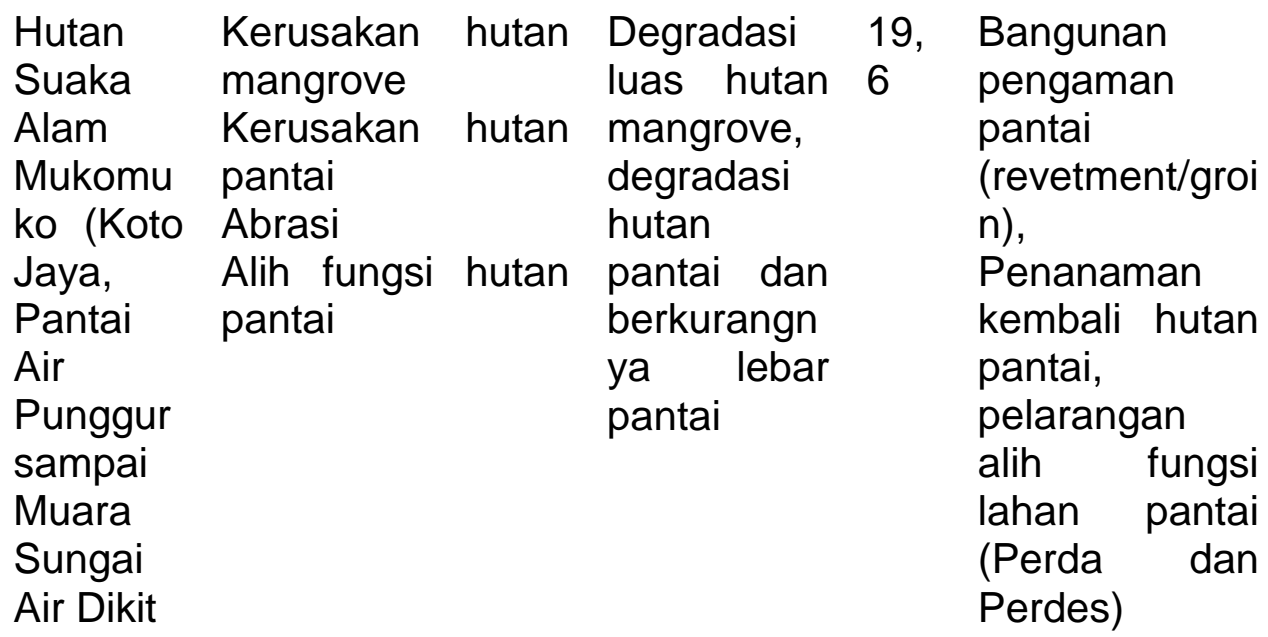

3 Pantai Kerusakan hutan Dec

Desa Air pantai

Dikit

Perubahan

sampai morfologi pantai,

gradasi

19, Penanaman

Pondok

Abrasi, Alih fungsi

Kubang

hutan pantai

luas hutan 6

pantai, dan

kembali hutan

pantai,

pelarangan

alih fungsi

lahan pantai

(Perda dan

Perdes)

4 Pasar Kerusakan hutan Degradasi 24, Penanaman

Bantal pantai Alih fungsi luas hutan 0 kembali hutan

(Muara hutan pantai pantai

pantai,

pelarangan

Sungai Pemukiman

Batang Fasilitas perikanan

alih fungsi

lahan pantai

Nelan-

Muara

Air

Teraman

(Perda dan

Perdes) dan

pengaturan

g

5 Air

Kerusakan hutan Degradasi

pemukiman

Hitam pantai Alih fungsi

(Taman

hutan pantai

hutan

pantai

12, Mengembalika Wisata

0 n TWA dengan penanaman vegetasi hutan pantai, penguatan dan penegakan aturan/hukum pengelolaan TWA Air Hitam 


$\begin{array}{lll}\begin{array}{l}\text { Retak llir } \\ \text { (Taman }\end{array} & \text { Kerusakan hutan } & \text { Degradasi } \\ \text { Wisata } & \text { morfologi pantai } & \text { hutan } \\ \text { Alam) } & \text { Abrasi, alih fungsi } & \text { berkurangn } \\ & \text { hutan pantai } & \text { ya lebar } \\ & & \text { pantai dan } \\ & \text { berubahnya } \\ & & \text { material } \\ & & \text { pantai }\end{array}$

Kerusakan pantai Abrasi dan alih fungsi hutan

Degradasi pantai

17, Penanaman

0 kembali vegetasi hutan pantai, pelarangan alih fungsi lahan pantai, penguatan dan penegakan aturan/hukum pengelolaan TWA Air Hitam

pantai

Pemukiman

55, Bangunan 1 pengaman pantai (revetment/groi n), pengatruran pemukiman

$\begin{array}{lll}\text { Air Buluh } & \text { Kerusakan hutan } & \text { Degradasi } \\ \text { pantai } & \text { hutan } \\ \text { Alih fungsi hutan } & \text { pantai } \\ \text { pantai } & & \end{array}$

22, Penanaman 6 kembali hutan pantai, pelarangan alih fungsi lahan pantai (Perda dan Perdes)

$\begin{array}{lll}9 \quad \text { Air Rami } & \begin{array}{l}\text { Kerusakan hutan } \\ \text { pantai }\end{array} & \begin{array}{l}\text { Degradasi } \\ \text { hutan }\end{array} \\ & \begin{array}{l}\text { Alih fungsi hutan } \\ \text { pantai }\end{array} & \\ & \text { pantai }\end{array}$
13, Penanaman
9 hutan pantai, pelarangan alih fungsi lahan pantai (Perda dan Perdes)

Sumber : Hasil analisis data primer (2014)

Pada Tabel 2 diatas, dapat diketahui bahwa disepanjang wilayah pesisir Kabupaten Mukomuko dijumpai ada 9 (sembilan) lokasi yang sudah mengalami kerusakan. Dari keseluruhan lokasi tersebut wilayah pesisir di Desa Pasar Ipuh menunjukkan tingkat kerentanan yang paling tinggi, dengan nilai $I P K=55,1$. Tingkat kerentanan yang paling rendah terdapat di Kawasan Taman Wisata Alam Air Hitam. Peta sebaran lokasi, jenis dan IKP kerusakan wilayah pesisir Mokomuko dapat dilihat pada Gambar 1. 


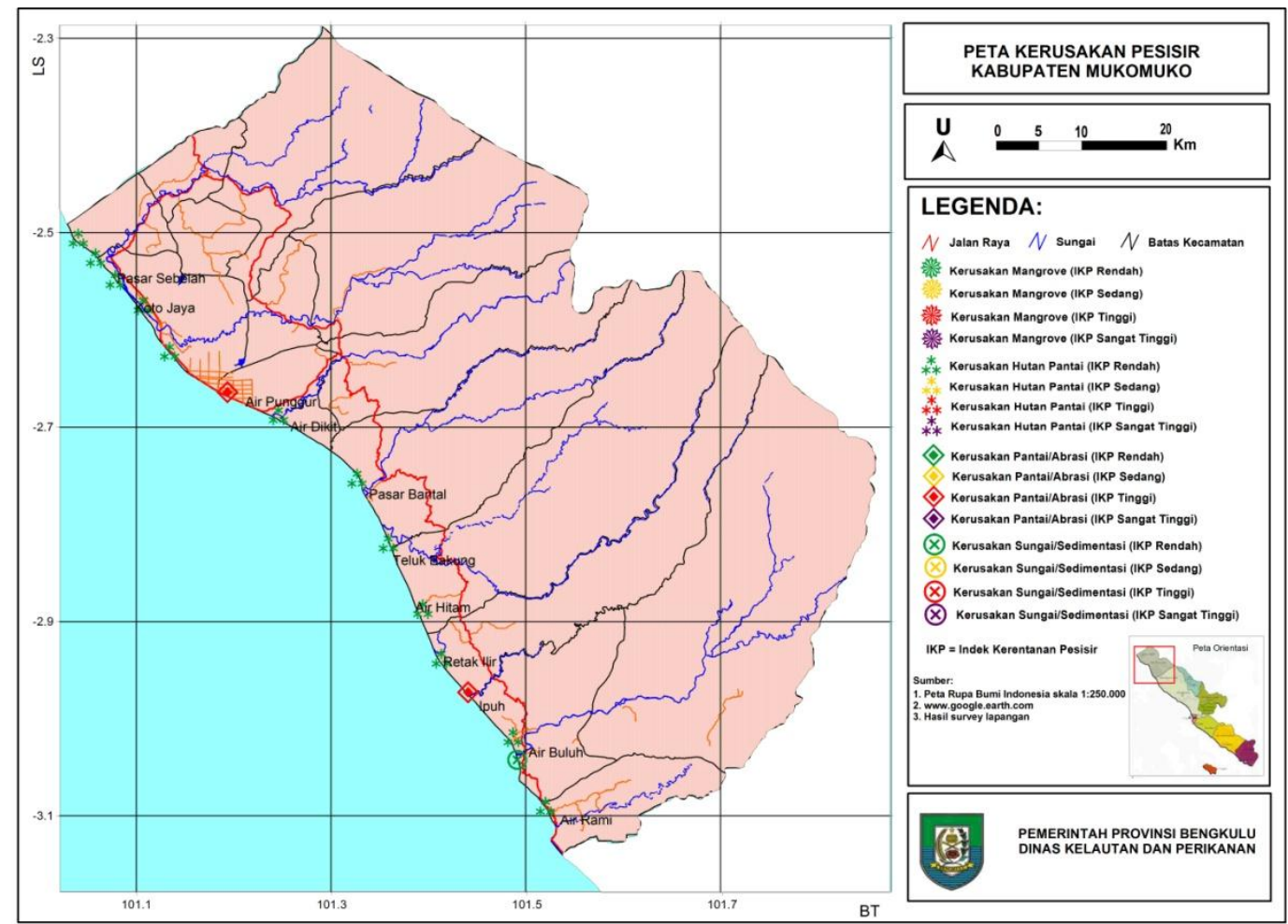

Gambar 1. Peta sebaran lokasi, jenis dan IKP kerusakan daerah pesisir Kabupaten Mukomuko, Provinsi Bengkulu (Sumber: Hasil analisis data primer, 2014)

Fenomena yang menarik dari kerusakan wilayah pesisir di Kabupaten Mukomuko adalah ditemukannya di setiap lokasi pengamatan kegiatan alih fungsi lahan pantai menjadi lahan pertanian, perkebunan dan pemukiman. Degradasi wilayah pesisir di Kabupaten Mukomuko di dominasi oleh abrasi pantai, seperti di Desa Pasar Ipuh, Retak llir, Air Dikit, Koto Jaya Kota Mukomuko, Rawa Bangun dan Pasar Sebelah. Ongkosongo (1997) dalam Rositasari (2001) menyebutkan bahwa, aspek utama pemicu perubahan di wilayah pesisir adalah proses anthropogenic dan alamiah, seperti juga wilayah pesisir di berbagai belahan bumi, Indonesia mengalami konversi lahan pesisir dalam skala besar.

Proses anthropogenic yang dimaksudkan disini adalah adanya tekanan dari manusia dalam mengeksploitasi sumberdaya alam di wilayah pesisir, sedangkan proses alamiah adalah seperti abrasi dan sedimentasi. Sebagaimana penjelasan dari Pramudyanto (2014), beberapa kegiatan pembangunan di kawasan daratan dan lautan, masih banyak yang memberikan dampak negatif pada lingkungan yang akhirnya berakibat pada menurunnya kualitas lingkungan pesisir dan laut maupun kelestarian sumberdaya alam, yaitu berupa pencemaran dan kerusakan lingkungan serta pemanfaatan yang berlebih atas sumberdaya pesisir dan laut. Zikra (2009), juga mengemukakan bahwa kerusakan pantai yang terjadi seperti disebutkan diatas umumnya diakibatkan oleh proses alami dari pengaruh hidrooceanografi setempat (arus, gelombang, angkutan sedimen) dan juga akibat campur tangan atau intervensi manusia terhadap daerah 
pantai. Seperti hilangnya tumbuhan yang berfungsi sebagai pelindung alami seperti yang disebutan diatas akibat alih fungsi menjadi perumahan nelayan atau areal tambak.

Kerusakan wilayah pesisir di beberapa tempat di Kabupaten Mukomuko sudah berdampak terhadap pemukiman, jalan raya dan berbagai prasarana yang ada di wilayah pesisir. Hal tersebut adalah sebuah gejala yang umum terjadi, seperti yang dikemukan oleh Wahyudi (2012), beberapa daerah di pesisir Kabupaten Tegal telah terjadi erosi pantai yang mengakibatkan pantai mundur 25 sampai $200 \mathrm{~m}$, di antaranya merusak tambak, kebun melati, mengancam tempat rekreasi, merusak dermaga pelabuhan, mengancam jalan nasional.

\section{KESIMPULAN}

Sepanjang wilayah pesisir Kabupaten Mukomuko, Provinsi Bengkulu, terdapat 9 titik lokasi kerusakan dengan Indeks Kerentanan Pesisir (IKP) secara berturut-turut yaitu Pantai Air Hitam-TWA (IKP=12), Pantai Air Rami (IKP=13,9), Rawa Bangun (IKP=14,7), Pantai Retak Ilir $(\mathrm{IKP}=17)$, Hutan Suaka Alam Mukomuko (IKP=19,6), Pantai Desa Air Dikit $(\mathrm{IKP}=19,6)$, Desa Pasar Bantal $(\mathrm{IKP}=24)$, Pantai Desa Air Buluh $(\mathrm{IKP}=22,6)$, dan Pantai Pasar Ipuh $(\mathrm{IKP}=55,1)$. Nilai IKP yang tertinggi adalah 55,1 dan yang terendah adalah 12.

Secara umum wilayah pesisir Kabupaten Mukomuko sudah mengalami degradasi. Tingkat kerusakan yang paling parah di kawasan pesisir pantai Desa Pasar Ipuh (IKP=55,1). Penyebab degradasi wilayah pesisir di Kabupaten Mukomuko, Provinsi Bengkulu antara lain adalah rusaknya hutan pantai, alih fungsi lahan, abrasi, perubahan morfologi pantai, pembangunan pemukiman, dan pembangunan sentra perikanan.

Kerusakan di wilayah pesisir di Kabupaten Mukomuko, Provinsi Bengkulu menimbulkan dampak/akibat yaitu degradasi luas hutan pantai berkurangnya lebar pantai, degradasi pantai, pendangkalan, perubahan morfologi, rusaknya fasilitas umum, dan berubahnya material pantai.

Alternatif penanggulangan atau rehabilitasi kerusakan daerah pesisir di di Kabupaten Mukomuko, Provinsi Bengkulu yang dapat dilakukan yaitu penanaman kembali hutan pantai, pelarangan alih fungsi hutan pantai (Perda/Perdes), pembuatan bangunan pengaman pantai (revetment/groin) atau pemecah gelombang, pengaturan pemukiman di wilayah pesisir-pantai, penguatan dan penegakan aturan/hukum pengelolaan TWA (Taman Wisata Alam)/CA (Cagar Alam). 


\section{DAFTAR PUSTAKA}

Bappeda Kabupaten Mukomuko, 2011. Rencana Tata Ruang Wilayah (RTRW) Kabupaten Mukomuko 2011-203. Pemerintahan Kabupaten Mukomuko.

Bryan J. Boruff, Christopher Emrich, and Susan L. Cutter, 2005. Erosion Hazard Vulnerability of US Coastal Countries. Journal of Coastal Research. 21 (5) : 932-942.

La Sara, 2014. Pengelolaan Wilayah Pesisir (Gagasan memelihara Aset Wilayah Pesisir dan Solusi Pembangunan Bangsa). Penerbit Alfabeta Bandung.

Pramudyanto, B., 2014. Pengendalian Pencemaran dan Kerusakan di Wilayah Pesisir. Jurnal Lingkar Widyaiswara. 1 (4) : 21-40.

Rositasari, R., 2001. Indonesia Menuju Manajemen Wilayah Pesisir Terintegrasi. Oseana. 26 (2) : 25-34.

Setyawan, W.B., Edi Kusmanto, M. Hasanuddin, Rahmi Y. Lutan, Sri Kusdi Rahayuningsih dan Muhajirin, 2015. Mengelola Kawasan Pesisir Yang Tererosi Secara Terpadu. Pusat Penelitian oseanografi LIPI, Jakarta.

Wahyudi, 2012. Geologi Lingkungan Kawasan Pesisir. Sosialisasi Geologi Lingkungan Dalam Rangka Pengembangan Wilayah Pesisir Di Jawa Timur Tahun 2012. Pusat Studi Kebumian, Bencana, Dan Perubahan Iklim, (Pskbpi) LPPM-ITS Jurusan Teknik Kelautan, FTK-ITS Malang, 6-7 Juni 2012.

Wahyudi, Teguh Hariyanto dan Suntoyo, 2009. Analisa Kerentanan Pantai di Wilayah Pesisir Pantai Utara Jawa Timur. SENTA.

Wibisono, M.S., 2011. Pengantar IImu Kelautan. Edisi 2. Penerbit Universitas Indonesia (UI) Press.

Zikra, M., 2009. Kegiatan Survey Lapangan Untuk Inventarisasi Permasalahan Kerusakan Pesisir Pantai Di Kabupaten Tegal, Jawa Tengah. Jurnal Kelautan. 2 (1) : 22-29. 